\title{
Determination of the Appropriate Inoculum Dose and Incubation Period of Cassava Leaf Meal and Tofu Dreg Mixture Fermented with Rhizopus Oligosporus
}

\author{
Annisa $^{1}$, Yose Rizal ${ }^{2 *}$, Mirnawati ${ }^{2}$, Irfan Suliansyah ${ }^{3}$ and Amri Bakhtiar ${ }^{4}$ \\ ${ }^{I}$ PhD Student at Graduate Program, Universitas Andalas, Padang, 25163, Indonesia \\ ${ }^{2}$ Lecturer at Faculty of Animal Science, Universitas Andalas, Padang, 25163, Indonesia \\ ${ }^{3}$ Lecturer at Faculty of Agriculture, Universitas Andalas, Padang, 25163, Indonesia \\ ${ }^{4}$ Lecturer at Faculty of Pharmacy, Universitas Andalas, Padang, 25163, Indonesia \\ *Corresponding author's Email: yrizal@ansci.unand.ac.id; (DORCiD: 0000-0003-3010-126x
}

\begin{abstract}
The present study was conducted to determine the appropriate inoculum dose and incubation period for the mixture of Cassava Leaf Meal (CLM) and Tofu Dreg (TD) fermented with Rhizopus oligosporus. This experiment was carried out in a completely randomized design in a $3 \times 4$ factorial treatments arrangement with 4 replications. The first factor was the inoculum dose $(6,8$ and 10\%), and the second factor was the incubation period of the fermentation (2, 3, 4, and 5 days). Measured variables were the changes in Dry Matter (DM), Organic Matter (OM), crude fat, Crude Fiber (CF), and Crude Protein (CP). The experimental results showed that there was no interaction between the inoculum dose and an incubation period of the fermentation in the reduction of DM, organic matter, and crude fat as well as the increase in the CP of fermented CLM and TD with Rhizopus oligosporus. However, the interaction was occurred between inoculum dose and incubation period in the reduction in CF. The inoculum dose significantly decreased the DM, OM, crude fat and CF and also increased the CP. The best inoculum dose effect was at $10 \%$. The incubation period had a significant reduction in the DM, OM, crude fat, and CF and also increased the CP. The best incubation period of fermentation was at 3 days. The results indicated that the appropriate inoculum dose to ferment CLM and TD mixture with Rhizopus oligosporus was $10 \%$ at each incubation period. In the meanwhile, the appropriate incubation period was 3 days for each inoculum dose.
\end{abstract}

Keywords: Fermentation, Inoculum dose, Incubation time, Rhizopus oligosporus

\section{INTRODUCTION}

Cassava Leaf Meal (CLM) has been widely studied as a feed ingredient in a mixture of chicken rations because it contains quite high crude protein. According to Iheukwumere et al. (2008), CLM contains dry matter 25.30\%, crude protein $25.1 \%$, crude fiber $11.4 \%$, crude fat $12.7 \%$, nitrogen retention $46.1 \%$, and ash $9.1 \%$. Although the protein content of CLM is quite high, it cannot be utilized in large quantities in poultry rations because it contains high crude fiber and HCN. The CLM could only be used up to $5 \%$ in broiler chicken rations because the utilization of up to 10 and $15 \%$ reduced the efficiency of feed conversion (Melesse et al., 2018; Wyllie and Chamanga, 1979). According to Ravindran et al. (1986) and Eggum (1970), the utilization of cassava leaves is still limited due to high CF, tannins, HCN, alkalis, low digestibility and deficiency of sulfur-containing amino acids, especially methionine. To improve the quality of CLM, it needs to be processed. One of the processing methods that can be done is by fermentation method. Fermentation is a process of microorganism or microbial activity that can produce a product whose texture, taste, aroma, and nutritional quality changes better than the raw material and result in an increase in the quality and nutritional content of feed ingredients (Aisjah and Abun, 2012; Mirnawati et al., 2019a). Fermentation of cassava waste has been carried out by many researchers, including Sugiharto (2019), who performed a solid-fermentation with fungi which was a simple method to improve the nutrient qualities of cassava pulp and thus increased the production of such a cheap agroindustrial by-product in chicken rations. Therefore, microbes were needed to overcome all of the problems of CLM as a feed ingredient. Yuniza et al. (2017) found that the fermentation of the combination of CLM and palm kernel cake by using Bacillus amyloliquefaciens improved the nutritional values of this fermented mixture of CLM and palm kernel cake. In the present study, therefore, microbes were needed that could overcome all problems of cassava leaves as feed component. According to Han et al. (2003), Dewi (2015) and Sumiati et al. (2011), Rhizopus oligosporus produces enzymes such as protease, lipase, alfa-amylase, glutaminase, and alfa-galactosidase and cellulase. The presence of the enzymes produced by Rhizopus oligosporus, is expected to reduce anti-nutrients and toxins content in CLM while increasing its nutritional values.

The success of solid fermentation is dependent heavily on the optimal conditions that exist. Some factors that influence solid fermentation are substrate composition, inoculum dosage and fermentation time/incubation period. The 
composition of the substrate must be considered as it affects the enzymes produced by microbes. Microbes produce enzymes based on the availability of inducers in the substrate. Therefore, in the present study the addition of tofu dregs (TD) as a combination of CLM substrate aims to provide the adequacy of nitrogen sources.

The inoculum dose and incubation period of the fermentation also affect fermentation. The higher the dose of the inoculum, the more microbe grow, and the longer the incubation period of fermentation, the more chances for microbes to break down nutrients in the substrate (Mirnawati et al., 2012; Mirnawati et al., 2013; Mirzah and Muis, 2015; Mirnawati et al., 2019b). Thus, the combination of inoculum dose and incubation period of fermentation might improve the quality of CLM and TD. However, with the increasing in incubation period, the availability of nutrients in the fermentation media was exhausted, so that the bacteria would eventually die and thereby the decline in organic matter was reduced (Agustina et al., 2015; Iwansyah et al., 2019). In order to obtain the optimal conditions, it was necessary to determine the best inoculum dose and incubation period for the fermentation of CLM and TD mixture with Rhizopus oligosporus.

\section{MATERIALS AND METHODS}

The present study aimed to investigate the effects of inoculum dose and incubation period of CLM and TD mixture that were fermented with Rhizopus oligosporus on the alteration in DM, OM, crude fat, $\mathrm{CF}$ and $\mathrm{CP}$, and to determine the appropriate inoculum dose and incubation period for the fermentation process.

\section{Materials}

The materials used in this study consisted of CLM, TD, Rice Bran (RB), Rhizopus oligosporus, Potato Dextrose Agar and brook minerals (Brook et al., 1969). This CLM was taken from the cassava waste when the cassava farmers harvested the roots. The cassava leaves were obtained from the two-thirds of the shoots or from the top part (where the leaves were still green). The equipment used in this study consisted of $5 \mathrm{~kg}$ capacity scale, $1 \mathrm{~kg}$ glass plastic size, autoclave, test tube, laminar flow, incase, oven, grinding machine and a set of proximate apparatus.

\section{Methods}

This experiment was carried out by the experimental method using a completely randomized design in a $3 \mathrm{x} 4$ factorial treatment arrangements with 4 replications. The first factor was the fresh inoculum dose (D refers to inoculum dose, D6 $=6 \%$, D8 $=8 \%$, and D10 = 10\%). The second factor was the incubation period ( $\mathrm{L}$ refers to long term fermentation, $\mathrm{L} 2=2$ days, $\mathrm{L} 3=3$ days, $\mathrm{L} 4=4$ days, and L5 $=5$ days). Measured variables were alteration in DM, OM, crude fat, $\mathrm{CF}$, and $\mathrm{CP}$ after fermentation.

\section{Data collection}

The CLM was prepared by drying CLM in the sun and then grinding it in a finely milled two mm filter size. The Rhizopus oligosporus inoculum was the RB and CLM mixture at the ratio of $90 \%$ to $10 \%$. Then, the substrate composition consists of $80 \%$ CLM and $20 \%$ TD. Finally, the fermentation process was carried out. The fermentation of CLM and TD by using Rhizopus oligosporus was performed with the inoculums dose of $6,810 \%$ and incubation period of 2, 3, 4 and 5 days according to the treatment. This fermentation process was as follows: each of the CLM-TD samples was inserted into a heat-resistant and homogenized glass plastic, afterwards the samples, distilled water, and fermentation equipment were sterilized with autoclave, at a pressure of $15 \mathrm{lbs}$, and temperature $121^{\circ} \mathrm{C}$ for 15 minutes, and then cooled in laminar flow and UV for 15 minutes. In the next step the inoculum was dissolved in accordance with the treatment in $27 \mathrm{ml}$ water that was sterilized (as an addition of water to 45-65\%), then it had put into plastic substrate, then homogenized, fixed surface, and covered with plastic clips, and pierced with sterile sticks flat surface. Subsequently, the samples were incubated in open incase of airflow for 2, 3, 4 and 5 days according to the treatment (facultatively anaerobic). After completing the fermentation process according to the treatment, the DM, OM, crude fat, CF and CP of samples were analyzed according AOAC (1990) procedures.

\section{Data Analysis}

The data obtained were analyzed statistically using analysis of variance of completely randomized design in a $3 \times 4$ factorial treatment arrangements. If there was a real effect, then the Duncan's Multiple Range Test (DMRT) according to Steel and Torrie (1980) should be used to test the significant differences among treatment means.

\section{RESULTS}

The effects of inoculum dose and incubation period of fermentation of CLM and TD mixture with Rhizopus oligosporus on the alterations in DM, OM, crude fat, $\mathrm{CF}$ and $\mathrm{CP}$ are shown in table 1. 
Table 1. Effect of inoculum dose and the incubation period of cassava leaves and tofu dregs fermented with Rhizopus oligosporus on the reductions of dry matter, organic matter, crude fat, crude fiber and the increase in crude protein in the Non-Ruminant Nutrition Laboratory, at the Faculty of Animal Husbandry, Andalas University, Padang, Indonesia in January 2019.

\begin{tabular}{|c|c|c|c|c|c|c|}
\hline \multirow{2}{*}{ Observed variables } & \multirow{2}{*}{$\begin{array}{c}\text { Inoculum dose } \\
(\%)\end{array}$} & \multicolumn{4}{|c|}{ Incubation period (days) } & \multirow{2}{*}{ Average } \\
\hline & & $\mathbf{L 2}$ & $\mathbf{L 3}$ & L4 & $\mathbf{L 5}$ & \\
\hline \multirow{4}{*}{$\begin{array}{l}\text { Reduction in dry } \\
\text { matter }(\%)\end{array}$} & D6 & 0.67 & 0.83 & 0.82 & 0.81 & $0.78^{\mathrm{b}}$ \\
\hline & D8 & 0.68 & 0.84 & 0.82 & 0.82 & $0.79^{b}$ \\
\hline & D10 & 0.72 & 0.86 & 0.84 & 0.84 & $0.82^{\mathrm{a}}$ \\
\hline & Average & $0.69^{c}$ & $0.84^{\mathrm{a}}$ & $0.83^{b}$ & $0.82^{b}$ & \\
\hline \multirow{4}{*}{$\begin{array}{l}\text { Reduction in organic } \\
\text { matter }(\%)\end{array}$} & D6 & 2.96 & 3.82 & 3.36 & 3.44 & $3.40^{\mathrm{b}}$ \\
\hline & D8 & 3.04 & 3.86 & 3.62 & 3.45 & $3.49^{\mathrm{b}}$ \\
\hline & D10 & 3.10 & 3.86 & 3.91 & 3.70 & $3.64^{\mathrm{a}}$ \\
\hline & Average & $3.04^{\mathrm{c}}$ & $3.85^{\mathrm{a}}$ & $3.63^{b}$ & $3.53^{\mathrm{b}}$ & \\
\hline \multirow{4}{*}{$\begin{array}{l}\text { Reduction in crude fat } \\
(\%)\end{array}$} & D6 & 14.04 & 24.30 & 24.19 & 23.93 & $21.62^{b}$ \\
\hline & D8 & 14.24 & 24.22 & 24.20 & 24.32 & $21.74^{\mathrm{b}}$ \\
\hline & D10 & 14.69 & 25.47 & 24.82 & 24.71 & $22.42^{\mathrm{a}}$ \\
\hline & Average & $14.32^{\mathrm{c}}$ & $24.66^{\mathrm{a}}$ & $24.40^{\mathrm{b}}$ & $24.32^{b}$ & \\
\hline \multirow{4}{*}{$\begin{array}{l}\text { Reduction in crude } \\
\text { fiber }(\%)\end{array}$} & D6 & $18.27^{\mathrm{c}}$ & $25.36^{\mathrm{b}}$ & $24.66^{b}$ & $24.66^{b}$ & $23.24^{b}$ \\
\hline & D8 & $18.39^{\mathrm{c}}$ & $26.05^{b}$ & $25.27^{\mathrm{b}}$ & $24.90^{\mathrm{b}}$ & $23.65^{b}$ \\
\hline & D10 & $24.73^{b}$ & $27.40^{\mathrm{a}}$ & $26.40^{b}$ & $25.86^{b}$ & $26.10^{\mathrm{a}}$ \\
\hline & Average & $20.46^{c}$ & $26.27^{\mathrm{a}}$ & $25.44^{b}$ & $25.14^{b}$ & \\
\hline \multirow{4}{*}{$\begin{array}{l}\text { Increase in crude } \\
\text { protein }(\%)\end{array}$} & D6 & 22.40 & 25.44 & 23.51 & 23.84 & $23.80^{b}$ \\
\hline & D8 & 22.44 & 26.92 & 24.97 & 24.39 & $24.68^{b}$ \\
\hline & D10 & 24.07 & 28.47 & 27.20 & 25.79 & $26.38^{\mathrm{a}}$ \\
\hline & Average & $22.97^{\mathrm{c}}$ & $26.94^{\mathrm{a}}$ & $25.23^{b}$ & $24.67^{b}$ & \\
\hline
\end{tabular}

$\overline{\mathrm{a}, \mathrm{b}, \mathrm{c},}$ : Different in superscripts at the same rows and columns of each variable indicate significantly different effects (p < 0.05$).$

\section{Reduction in dry matter}

The result of experiment showed that there was no interaction between the inoculum dose and the incubation period of CLM and TD mixture fermented with Rhizopus oligosporus in the reduction in DM. The inoculum dose showed a significant effect $(\mathrm{p}<0.05)$ on decreasing in DM. Further DMRT test indicated that inoculum dose had showed that D6 treatment had no difference with D8 treatment. However, D6 and D8 treatments were significantly different from D10 treatment. The incubation period showed a significant effect $(\mathrm{p}<0.05)$ on the reduction in DM from the fermentation of CLM and TD mixture with Rhizopus oligosporus. The results of the DMRT indicated that the incubation period of L2 treatment was significantly different from L3, L4, and L5 treatments. L3 treatment was significantly different from L4 and L5. Then the L4 treatment was not different from the L5 treatment. The highest reduction in DM was found in the inoculum dose of $10 \%$. The more reduction in DM was found at the incubation period of 3 days. The reduction in DM increased with the incubation time of 3 days, compared to the incubation time of 2 days, then decreased again after 4 days and 5 days. Reduction in DM indicated that the optimal incubation period for CLM and TD mixture fermented with Rhizopus oligosporus was 3 days.

\section{Reduction in organic matter}

Based on the results of an analysis of variance, it was found that there was no interaction between the inoculum dose and incubation period of CLM and TD mixture fermented with Rhizopus oligosporus to reduce OM. The inoculum dose showed a significant effect ( $\mathrm{p}<0.05$ ) on the reduction in OM of CLM and TD mixture fermented with Rhizopus oligosporus. Based on the result of further tests using DMRT showed that D6 treatment was not different from D8 treatment. Furthermore, D6 and D8 treatments were significantly different from D10 treatment. The incubation period showed a significant effect $(\mathrm{p}<0.05)$ on the reduction in OM of CLM and TD mixture fermented with Rhizopus oligosporus. The result of DMRT of incubation period showed that L2 treatment was significantly different from L3, L4, and L5 treatments. L3 treatment was significantly different from L4 and L5 treatments. Meanwhile, L4 treatment was not different from L5 treatment. In the inoculum dose factor, the highest reduction in OM was found at the inoculum dose of $10 \%$. Increasing the inoculum dose had a positive effect on the reduction in OM. During the incubation period, the greatest reduction in $\mathrm{OM}$ was found in the incubation period of 3 days. The reduction in OM increased during incubation period of 3 days compared to the incubation period of 2, 4 and 5 days. The result of experiment showed that the incubation period of 3 days was the optimal one for fermenting of CLM and TD mixture with Rhizopus oligosporus. 


\section{Reduction in crude fat}

From the result of the analysis of variance, it was obtained that there was no interaction $(p>0.05)$ between the inoculum dose and incubation period of CLM and TD mixture fermented with Rhizopus oligosporus in the reduction in crude fat. The inoculum dose significantly affected $(\mathrm{p}<0.05)$ the reduction in crude fat. The results of the DMRT analysis showed that D6 treatment was not significantly different from D8 treatment. Furthermore, D6 treatment was significantly different from D10 treatment.

The results of the analysis variance of incubation period showed a significant effect $(\mathrm{p}<0.05)$ on the reduction in the crude fat of cassava leaves and tofu dregs were fermented with Rhizopus oligosporus. The DMRT test results showed that the L2 treatments differed significantly from L3, L4, and L5 treatments. In addition, L3 treatment was significantly different from L4 and L5 treatments. Then L4 treatment did not differ significantly from L5 treatment.

In the inoculum dose factor, the highest decrease in crude fat was found at the treatment of the $10 \%$ inoculum dose The increasing inoculum dose had a positive effect on the reduction in crude fat. In the incubation period, the highest decrease in crude fat was found in the incubation period of 3 days. The reduction in crude fat increased at an incubation period of 3 days when compared to a 2 days incubation period, then decreased again at 4 days and 5 days. The incubation period of 3 days was the optimal for fermentation of cassava leaves and tofu dregs with Rhizopus oligosporus.

\section{Reduction in crude fiber}

Based on the results of the analysis variance, showed that there was an interaction $(p<0.05)$ between the dose of inoculum and the incubation period of cassava leaves and tofu dregs was fermented with Rhizopus oligosporus on the decrease in CF. Based on the results of the DMRT test the highest the decrease in CF was found in the treatment of D10L3, then D10L4, D10L5, D10L2, D8L3, D8L4, D8L5, D6L3, D5L4, D6L5, D8L2, and D6L2. This is caused by the fact that the higher the dose of inoculum the more the decrease in $\mathrm{CF}$, the better the effect on increasing the nutritional value of fermented feed ingredients with Rhizopus oligosporus. Increasing the dose had a positive effect on the decrease in CF later. The incubation period in the treatment of 3 days was the optimal time to ferment cassava leaves and tofu dregs with Rhizopus oligosporus. The longer the fermentation time used, the ingredients were overhauled by enzymes. However as the fermentation time increased, the availability of nutrients in the fermentation media decreased, so that the microbes eventually died and the CF was reduced.

\section{Increase in crude protein}

Based on the results of the analysis of variance, it was found that there was no interaction $(p>0.05)$ between inoculum dose and fermentation period of a cassava leaf and fermented tofu dregs with Rhizopus oligosporus to increase $\mathrm{CP}$. The results of the analysis variance of inoculum dose factors indicated a significant $(\mathrm{p}<0.05)$ increase in CP fermented from cassava leaves and tofu dregs with Rhizopus oligosporus. Based on the DMRT test, it was found out that although D6 treatment was not significantly different from D8 treatment, but it was significantly different from D10 treatment. Increasing the inoculum dose had a positive effect on the increase in CP.

The incubation period factor also influenced $(\mathrm{p}<0.05)$ the increase in CP from cassava leaves and TD mixture fermented with Rhizopus oligosporus. The DMRT test results indicated that L2 treatment was significantly different from L3, L4, and L5. L3 treatment was significantly different from L4 and L5. Then, L4 treatment was not significantly different from L5 treatment. The highest increase in CP was found at an incubation period of 3 days. Thus, the optimal incubation period was 3 days for fermented of cassava leaves and tofu dregs with Rhizopus oligosporus.

\section{DISCUSSION}

\section{Reduction in dry matter}

The reduction in DM could be an indicator of the success of fermentation, since the fermentation process could decrease the amount of DM and increase the use of nutrients from the substrate by microbes as a source of carbon, nitrogen, and minerals, and release of $\mathrm{CO} 2$ and energy in the form of heat that evaporates with air particles created by the catabolic process that transform complexes into simpler materials (Astuti et al., 2017). The more mold grew, the more substance was in the substrate material, which was renewed as an energy source. The increase in water molecules resulting from the mold growth also increased (Kasmiran, 2011).

The reduction in DM also depended on the incubation period factor. The reduction in DM began to tie up for 3 days and began to decrease for 4 days, and this reduction happened because the longer the incubation period was used, the more nutrients were overtaken by enzymes. However, as the incubation period increased, the availability of nutrients in the fermentation media became increasingly limited, which led to decreased microbial growth and ultimately to death (Agustina et al., 2015; Iwansyah et al., 2019). According to Wang et al. (1979), the growth of microbes has reached a stationary phase, the growth rate would decrease due to increased use of food and the accumulation of metabolic substances which inhibit the growth and the growth rate. That condition was increased until the value became zero (the 
number of growing cells corresponds to the number of dying cells), then the total cell mass was constant and the number of living cells continued to decrease due to lysis.

\section{Reduction in organic matter}

The reduction in OM indicated a better fermentation process by increasing the provision of tofu dregs compared to the without fermentation. The reduction in DM showed success indicators of fermentation as the fermentation process reduced the amount of $\mathrm{OM}$, due to the use of nutrients from the substrate by microbes as a carbon source, nitrogen and minerals, and release of $\mathrm{CO} 2$ and energy in the form of heat that evaporates with air particles whereby water molecules were formed from catabolic processes that convert complex compounds into simpeler materials (Astuti et al., 2017). The reduction in OM caused to decrease in the nutrients supply of the overhauled material that has been utilized by mold (Kasmiran, 2011).

The reduction in $\mathrm{OM}$ at the incubation duration factor was limited to 3 days and began to decrease after 4 days. The $\mathrm{OM}$ reduction happened because the longer the incubation period, the more ingredients were overhauled by enzymes produced by microbes. With increasing incubation period, however, the availability of nutrients in the fermentation media would exhausted, so that the bacteria will eventually die off, thereby reducing the reduction in OM (Agustina et al., 2015; Iwansyah et al., 2019). Moreover, Wang et al. (1979) explained that the growth rate of microbes decreased due to the declining in nutrients supply when they reached stationary phase, and the microbes died overtime.

\section{Reduction in crude fat}

The reduction in crude fat caused by lipase enzymes produced by Rhizopus oligosporus converted fat content into lighter fatty acids (Yuliani, 2008). The higher reduction in crude fat in the substrate was eventually caused by increasing the inoculum dose.

The reduction in crude fat with the incubation period factor increased with the incubation period of 3 days and began to decrease with the incubation period of 4 days. The reduction in crude fat happened because the longer the fermentation incubation had been used, the more ingredients were degraded by enzymes produced by microbes. However, with the increasing in incubation period, the availability of nutrients in the fermentation media decreased, so that the microbes eventually died, and the reduction in crude fat also declined (Agustina et al., 2015; Iwansyah et al., 2019).

\section{Reduction in crude fiber}

The reduction in $\mathrm{CF}$ was reduced due to heat due to the fermentation process, whereby the binding of fibers could be broken down into simpler bonds, thereby increasing the dissolved fiber and decreasing the CF. Rhizopus oligosporus with a substrate made from a mixture of cassava leaves and tofu pulp as an inducer could use the carbohydrates and hemiselolosa contained in the substrate as an energy source for the metabolism, so that the rough fiber decreased (Wattiheluw, 2012). In addition, the reduction in CF was also caused by cellulase enzymes produced by the fungus Rhizopus oligosporus. Mold secreted enzymes according to the inductors available in the substrate (Mirza, 2019). Cassava leaves and tofu dregs as inducers in the substrate contain CF which could induce Rhizopus oligosporus to secrete cellulase enzymes which are needed to degrade the available fiber in the substrate. Rhizopus oligosporus cellulase enzymes could degrade carbohydrates and hemicelluloses such as galactose and pentose into simpel sugars and then used for the growth of these molds to about 50 percent (Wattiheluw, 2012).

The reduction in CF increased with increasing in inoculum doses, since the reduction in CF declined.. The success of solid medium fermentation was highly dependent on the optimal conditions. Some factors that influence solid media fermentation were substrate composition, substrate thickness, inoculum dosage, fermentation period, temperature and $\mathrm{pH}$. The longer the incubation period used, the more ingredients were broken down by enzymes. However, as incubation period increased, the availability of nutrients in the fermentation medium decreased, so that the microbes eventually had died and then the reduction in CF decreased (Agustina et al., 2015; Iwansyah et al., 2019).

\section{Increase in crude protein}

The increase in CP occurred because of the protein was donated by microbial cells. Increased in growth resulted in a Single Cell Protein (SCP) product or cell biomass containing approximately 40-65\% protein (Krishna et al., 2005). During the fermentation process, the microbes released enzymes, which was a protein, and the microbe itself was also a source of single-cell protein. According to Han et al. (2003), R. Oligosporus produces the enzymes including protease, lipase, a-amylase, glutaminase, and a-galactosidase. According to Dewi (2015), R. Oligosporus also produces cellulase, B-glucosidase, tananase, phytase enzymes. The presence of these enzymes was expected to overcome all limiting factors, reduce anti-nutrients and toxins contained in cassava leaves, while increasing their nutritional value (Sumiati et al., 2011). The presence of body cells and enzymes produced by $R$. oligosporus during the fermentation of cassava leaves and tofu dregs could increase the $\mathrm{CP}$ of the substrate because the body cells and these enzymes are proteins. 
According to Mirzah and Muis (2015) and Mirnawati et al. (2019b) the more CP would be produced when the inoculum dose was increased because the higher inoculum dose resulted in more microbes to degrade substrates. The increase in CP in 3 days and began to decrease in 4-5 days. This happened because the longer the fermentation time used, the more ingredients were degraded by enzymes. However, with the increase in fermentation time, the availability of nutrients in the fermentation medium decreased and the bacteria eventually had died, so that CP decreased (Agustina et al., 2015; Iwansyah et al., 2019).

\section{CONCLUSION}

The inoculum dose as well as incubation period affected the chemical composition of CLM and TD mixture fermented with Rhizopus oligosporus. The fermentation process altered DM, OM, crude fat, CF, and CP. There was a reduction in $\mathrm{DM}$, OM, crude fat and CF, but an increase in crude protein of fermented CLM and TD mixture. The appropriate inoculum dose for fermenting the CLM and TD mixture with Rhizopus oligosporus was $10 \%$ for each incubation period, while the appropriate incubation period for this fermentation was 3 days for each inoculum dose.

\section{DECLARATIONS}

\section{Acknowledgements}

This research was funded by the Ministry of Research Technology and Higher Education of the Republic of Indonesia under the PMDSU program with the contract number: 050/SP2H/LT/DRPM/2018. We are very grateful to the Ministry of Research Technology and Higher Education of the Republic of Indonesia and Rector of the Universitas Andalas for their supports in this program.

\section{Author's contribution}

Annisa and Yose Rizal participated in writing and revising the final edition of the manuscript. Mirnawati, Irfan Suliansyah, and Amri Bakhtiar participated in design of the experimental procedure of the manuscript. All authors confirm the final accepted article.

\section{Competing interests}

The authors have declared that no competing interest exists.

\section{Consent to publish}

The authors guarantee that this work has not been published elsewhere and any person named as a co-author of this study is aware of the facts and has agreed to the designation.

\section{REFERENCES}

Agustina Y, Kartika R and Panggabean AS (2015). Effect of variations in fermentation time on levels of lactose, fat, pH, and acidity in cow's milk fermented into yogurt. Jurnal Kimia Mulawarman (Journal of Mulawarman chemistry), 12(2), 97-100. Available at: http://jurnal.kimia.fmipa.unmul.ac.id/index.php/JKM/article/view/9

Aisjah T and Abun (2012). Bioprocess of winged beans seeds (Psophocarpus tetragonolobus (L) DC) by Rhizopus oligosporus to improve of pure protein content and decreased of cyanide. Jurnal Ilmu Ternak (Journal of Animal Science) 12(1): 35-40. DOI: https://doi.org/10.24198/jit.v12i1.5135

AOAC (1990). Official Methods of Analysis. Association of Official Analytical Chemists. The Association: Arlington, VA, Vol. II, 15th edition. Section. 985.29. DOI: https://doi.org/10.12691/jfnr-2-4-9

Astuti T, Rofiq MN and Nurhaita (2017). Evaluation of the content of dry matter, organic matter and crude protein of palm fronds fermentation with the addition of carbohydrate sources. Jurnal Peternakan (Journal of Animal Husbandry), 14 (2): $42-47.4$ DOI: https://doi.org/10.24014/jupet.v14i2.4247

Brook EJ, Stantion WR and Bridge AW (1969). Fermentation methods for protein enrichment of cassava. Biotechnology and Bioengineering, 11: 1271-1284. DOI: https://doi.org/10.1002/bit.260110620

Dewi S (2015). Isolation and identification of cellulolytic thermophilic fungi and examination of its cellulase enzyme activity. Thesis. Faculty of Agricultural Technology. Gadjah Mada University. Yogyakarta. Available http://etd.repository.ugm.ac.id/index.php?mod=penelitian_detail\&sub=PenelitianDetail\&act=view\&typ=html\&buku_id=87475\&obyek_id=4

Eggum BO (1970). The protein quality of cassava leaves. The British Journal of Nutrition, 24(3): 761-768. DOI: https://doi.org/10.1079/bjn19700078

Han B, Ma Y, Frans M, Rombouts MJ and Robert N (2003). Effects of temperature and relative humidity on growth and enzyme production by action mucorelegans and Rhizopus oligosporus during sufu pehtze preparation. Food Chemistry. 81: 27-34. DOI: https://doi.org/10.1016/S03088146(02)00347-3

Iheukwumere FC, Ndubuisi EC, Mazi EA and Onyekwere MU (2008). Performance, nutrient utilization and organ characteristics of broilers fed cassava leaf meal (Manihot esculenta Crantz). Pakistan Journal of Nutrition, 7 (1): 13-16. DOI: https://doi.org/10.3923/pjn.2008.13.16

Iwansyah AC, Patiya LG and Hervelly (2019). Effect of sodium chloride concentrations and fermentation time on physicochemical, microbial, and sensory of bamboo shoots kimchi. Industria: Jurnal Teknologi dan Manajemen Agroindustri (Journal of Agro-Industry Technology and Management), 8(3):227-237. DOI: https://doi.org/10.21776/ub.industria.2019.008.03.7 
Kasmiran A (2011). Effect of rice straw fermentation duration with local microorganisms on dry content, organic ingredients, and ash. Lentera (Lantern), 11(1):48-52. Available at: http://jurnal.umuslim.ac.id/index.php/LTRI/article/view/122

Krishna SBN and Devi KL (2005). Optimization of thermostable alkaline protease production from species of Bacillus using Ground nut cake. African Journal of Biotechnology, 4 (7): 724-726. DOI: http://dx.doi.org/10.5897/AJB2005.000-3132

Melesse A, Masebo M and Abebe A (2018). The substitution effect of noug seed (Guizotia abyssinica) cake with cassava leaf (Manihot Escutulata Crantz.) meal on feed intake, growth performance, and carcass traits in broiler chickens. Journal of Animal Husbandry and Dairy Science, 2(2): 1-9. Available at: https://www.researchgate.net/profile/Aberra_Melesse/publication/329567008_

Mirnawati, Ciptaan G and Djulardi A (2019a). Improving the quality and nutrient content of palm kernel cake through fermentation with Bacillus subtilis. Livestock Research for Rural Development, 31(7): 2019. Available at: www.lrrd.org/lrrd32/7/mirna31098.html

Mirnawati, Ciptaan G and Ferawati (2019b). The Effect of Bacillus subtilis inoculum doses and fermentation time on enzyme activity of fermented palm kernel cake. Journal World Poultry Research. 9(4): 211-216. DOI: https://dx.doi.org/10.36380/jwpr.2019.26

Mirnawati, Djulardi A and Marlida Y (2013). Improving the quality of palm kernel cake fermented by Eupenicillium javanicum as poultry ration. Pakistan Journal of Nutrition, 12 (12): 1085-1088. DOI: http://dx.doi.org/10.3923/pjn.2013.1085.1088

Mirnawati, Kompiang IP and Latif SA (2012). Effect of substrate composition and inoculums dosage to improve quality of palm kernel cake fermented by Aspergillus niger. Pakistan Journal of Nutrition, 11(5): 434-438. DOI: http://dx.doi.org/10.3923/pjn. 2012. 434.438.

Mirza R (2019). Study the nutritional quality of cocoa skin and fermented soybean husk using Rhizopus oligosporus as animal feed. Jurnal Ilmu Peternakan (Animal Husbandry Scientific Journal), 7 (1): 23-29. Available at: http://jurnal.umuslim.ac.id/index.php/JIP/article/view/1550

Mirzah and Muis H (2015). Improvement of Nutrition Quality of Cassava Skin Waste through Fermentation Using Bacillus amyloliquefaciens. Jurnal Ilmu Peternakan (Animal Husbandry Scientific Journal), 17 (2): 131-142. DOI: https://doi.org/10.25077/jpi.17.2.131-142.2015

Ravindran V, Kornegay ET, Rajaguru ASB, Potter LM and Cherry JA (1986). Cassava leaf meal as a replacement for coconut oil meat in broiler diets. Poultry Science, 65: 1720-1727. DOI: http://dx.doi.org/10.3382/ps.0651720

Steel RGD and Torrie JH (1980). Principles and Procedures of Statistics: A Biometrical Approach. 2nd edition. New York, USA: (McGraw-Hill, Inc.). pp. 187-188 and 336-376. Available at: https://www.scirp.org/(S(i43dyn45teexjx455qlt3d2q))/reference/ReferencesPapers.aspx?ReferenceID=383208

Sugiharto S (2019). A review on fungal fermented cassava pulp of as a cheap alternative feedstuff in poultry ration. Journal of World's Poultry research, 9(1): 01-06. DOI: https://dx.doi.org/10.36380/jwpr.2019.0

Sumiati, Farhanuddin, Hermana W, Sudarman A, Istichomah N and Setiyono A (2011). Broiler chicken performance given jatropha seed meal rations (Jatrophacurcas l.) fermented using Rhizopus oligosporus. Animal Husbandry Media, 34 (2): 117-125. DOI: https://doi.org/10.5398/medpet.2011.34.2.117

Wang DJC, Cooney CL, Deman AL, Numphrey AE and Lilly MD (1979). Fermentation and enzyme technology. John Willey and Sons, Inc. New York. DOI: https://doi.org/10.1016/0307-4412(80)90096-5

Wattiheluw MJ (2012). Effect of mixed kohay concentrate and fermented bran in Rhizopus oligosporus dosage on crude protein levels, crude fiber, and crude fat. Indonesian Journal of Applied Sciences, 2 (3): 95-99. DOI: https://doi.org/10.24198/ijas.v2i3.2741

Wyllie D and Chamanga PJ (1979). Cassava leaf meals in broiler diets. Tropical Animal Production. 4(3): 232-240. Available at: http://www.fao.org/WAICENT/FaoInfo/Agricult/aga/AGAP/FRG/TAP43/4_3_4.PDF

Yuliani (2008). Production of extracellular lipase from Rhizopus oligosporus RG2 in liquid state fermentation of sesame seed press-cake containing media. Journal of Agricultural Technology, 4(1): 31-40. Available at: https://jtpunmul.com/publications-2004-2008/vol-4-no-1/

Yuniza A, Nova TD, Angga WA, Annisa and Rizal Y (2016). Effects of the combinations of cassava leaf meal and palm kernel cake mixture fermented by Bacillus amyloliquefaciens on the alteration of their dry matter, crude protein, crude fiber, and crude lipid contents. Pakistan Journal of Nutrition, 15:1049-1054. DOI: https://dx.doi.org/10.3923/pjn.2016.1049.1054 